Special Issue of the 6th International Congress \& Exhibition (APMAS2016), Maslak, Istanbul, Turkey, June 1-3, 2016

\title{
Welding Time Effect of Welding Joints in Micro Alloyed and TRIP 800 Steels in Resistance Spot Welding
}

\begin{abstract}
V. ONAR* AND S. ASlanlar
Sakarya University, Faculty of Engineering, Department of Metallurgical and Materials Engineering, 54187 Sakarya, Turkey

This paper presents an analysis of resistance spot welds between micro alloyed steel sheets having $1 \mathrm{~mm}$ thickness and TRIP 800 (transformation-induced plasticity) steel sheets having $1.5 \mathrm{~mm}$. TRIP 800 steel and micro alloyed steel sheets are used in automobile chassis and automobile body parts, respectively. In this study, resistance spot-welding method was used for joining steel pairs to be lap joint. A time and current controlled resistance spot welding machine having $120 \mathrm{kVA}$ capacity, and pneumatic application mechanism were used in the experiments. Specimens prepared for spot welding operations were joined with different welding time ranging from 5 to 30 periods $(1$ period $=0.02 \mathrm{~s})$ and different weld currents, ranging from 8.5 to $16.5 \mathrm{kA}$ in $0.5 \mathrm{kA}$ steps. The electrode force was kept constant at $6 \mathrm{kN}$. Tensile-peel tests were applied to the welded specimens. The effect of welding time parameter on tensile-peel properties was analyzed. The highest tensile-peel load was obtained using 15 periods.
\end{abstract}

DOI: 10.12693/APhysPolA.131.389

PACS/topics: $81.20 . \mathrm{Vj}$

\section{Introduction}

Resistance spot welding (RSW) is generally used for mounting automobile steel sheets. The joint is obtained by combining heat, pressure, and time in this method. The resistance of the materials against the current flow causes a localized heating of the parts. That heat energy produces welded joint. RSW is the most qualitative and effective process for joining automobile body parts and chassis. Approximately 2000-5000 spot welds are used for the mounting of a new generation vehicle. At the present time, RSW is relevant for automation and has most advantages in comparison with the other sheet welding methods [1-6].

Transformation induced plasticity steels (TRIP) belong to the group of advanced high-strength steels (AHSS). The typical TRIP microstructure consists of martensite, bainite, and metastable retained austenite, embedded in a primary matrix of ferrite. TRIP steels provide combined high strength and good formability properties. Therefore, they are very important materials for manufacturing of automobile chassis [7-9].

Micro alloyed or high strength low alloy (HSLA) steels are preferred in automobile industry due to the better mechanical properties and greater corrosion resistance than those of the other steels. Micro alloyed steels are already used for body parts in automobiles.

TRIP and micro alloyed steels provide the decrease of the chassis and body structure weights. However, their safety and crash performance can be improved. The most important fact is that they affect fuel economy [10-12]. As a result, welding of these couple of steels is attractive for the automotive industry.

*corresponding author; e-mail: vonar@pau.edu.tr
In this paper, the relationship between tensile-peel strength and welding time of welded TRIP 800 and micro alloyed steels using RSW was investigated.

\section{Experimental studies}

In this study, TRIP 800 having $1.5 \mathrm{~mm}$ thickness and micro alloyed steel, having $1 \mathrm{~mm}$, sheets were used. Steel sheet couples are widely used in manufacturing of automobile chassis and body parts. The chemical properties of TRIP 800 and micro alloyed steel sheet are shown in Table I and Table II, respectively.

TABLE I

Chemical composition of TRIP 800 steel sheet (\%).

\begin{tabular}{c|c|c|c|c|c|c|c|c}
\hline \hline $\mathrm{C}$ & $\mathrm{P}$ & $\mathrm{Mo}$ & $\mathrm{Co}$ & $\mathrm{Ti}$ & $\mathrm{Sn}$ & $\mathrm{Si}$ & $\mathrm{S}$ & $\mathrm{Ni}$ \\
\hline 0.179 & 0.011 & 0.025 & 0.072 & 0.014 & 0.01 & 1.719 & 0.007 & 0.074 \\
\hline $\mathrm{Cu}$ & $\mathrm{V}$ & $\mathrm{Mg}$ & $\mathrm{Mn}$ & $\mathrm{Cr}$ & $\mathrm{Al}$ & $\mathrm{Nb}$ & $\mathrm{W}$ & $\mathrm{Fe}$ \\
\hline 0.1 & 0.013 & 0.001 & 1.691 & 0.065 & 0.027 & 0.053 & 0.04 & 95.902
\end{tabular}

TABLE II

Chemical composition of micro alloyed steel sheet (\%).

\begin{tabular}{c|c|c|c|c|c|c}
\hline \hline $\mathrm{C}$ & $\mathrm{Si}$ & $\mathrm{Mn}$ & $\mathrm{P}$ & $\mathrm{S}$ & $\mathrm{Ti}$ & $\mathrm{Fe}$ \\
\hline 0.12 & 0.50 & 0.60 & 0.10 & 0.45 & 0.30 & 97.93
\end{tabular}

The mechanical properties of TRIP 800 steel sheet are shown in Table III. Properties of micro alloyed steel sheets are shown in Table IV.

TABLE III

Mechanical properties of TRIP 800 steel sheet.

\begin{tabular}{c|c|c}
\hline \hline $\begin{array}{c}\text { Yield strength } \\
{[\mathrm{MPa}]}\end{array}$ & $\begin{array}{c}\text { Tensile strength } \\
{[\mathrm{MPa}]}\end{array}$ & $\begin{array}{c}\text { Total elongation } \\
{[\%]}\end{array}$ \\
\hline 480.3 & 785.8 & 25.1
\end{tabular}


TABLE IV

Mechanical properties of micro alloyed steel sheet.

\begin{tabular}{c|c|c}
\hline \hline $\begin{array}{c}\text { Yield strength } \\
{[\mathrm{MPa}]}\end{array}$ & $\begin{array}{c}\text { Tensile strength } \\
{[\mathrm{MPa}]}\end{array}$ & $\begin{array}{c}\text { Total elongation } \\
{[\%]}\end{array}$ \\
\hline 184 & 357 & 39
\end{tabular}

RSW technique was selected for welding of the steel sheets. This process was carried out between a couple of steel sheets using stable electrode form, constant cooling water flow rate, constant electrode force, and changing welding current and time. RSW machine with a single screen used in the current- and time-controlled experiments, had a pneumatic mechanism application system and a $120 \mathrm{kVA}$ capacity. During the welding processes, selected electrode force was continually controlled and measured. In addition, welding current values were calculated and controlled by an ampere-meter in the system. Additionally, another ampere-meter was used outside the machine system for continuous correlation of welding machine current values. Clamping time, hold time and welding time were set by electronic interface of the RSW machine. Conical $\mathrm{Cu}-\mathrm{Cr}$ electrodes, cooled with water, were preferred in the welding process. Contact surface diameter of these electrodes was regulated to be $6 \mathrm{~mm}$ for every joining.

Before welding, the specimens were cut to dimensions of $30 \times 180 \mathrm{~mm}^{2}$, as shown in Fig. 1a and cleaned ultrasonically. The specimens were over-lapped by $30 \mathrm{~mm}$ for welding (Fig. 1b, c). Welding time was set to 5, 10, 15, 20,25 and 30 cycles $(1$ cycle $=0.02 \mathrm{~s})$. The other welding parameters, such as electrode force $6 \mathrm{kN}$, clamping and hold times of electrode (25 cycles), were kept constant. The welding current was increased from 5 to $16.5 \mathrm{kA}$ by $0.5 \mathrm{kA}$ increments. Three of samples were prepared and tested for each parameter.

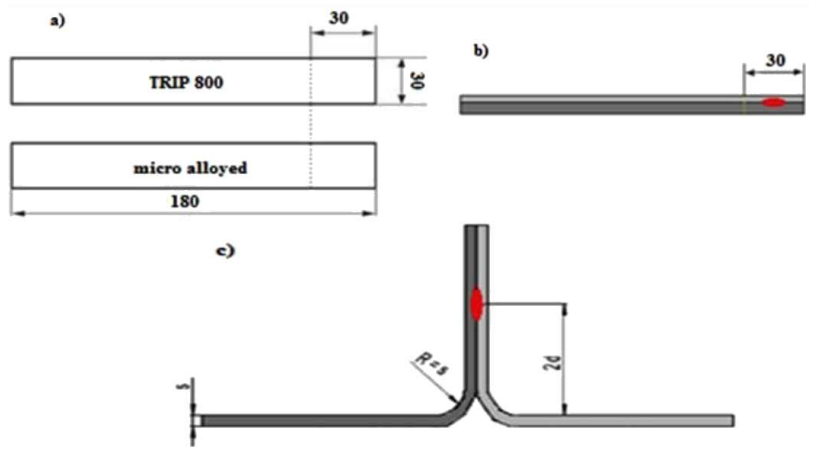

Fig. 1. The dimensions of the (a) parts of welding specimens, (b) welding specimens for tensile-peel test, (c) the tensile-peel specimens.

To measure the joint strength of welded specimens, tensile-peel tests were conducted with a Shimadzu Tensile Test Machine with 30 tons capacity. The welded specimens were put to the tensile test in laboratory environment. The tensile speed was kept at $20 \mathrm{~mm} / \mathrm{min}$ during test. The maximum tensile-peel strength was determined. The effects of welding time on the breaking failure modes of the specimens were investigated.

\section{Results and discussion}

As seen in Fig. 2, three types of breaking failure modes were obtained: (1) separation, (2) knotting, (3) tearing. Separation break failure mode was formed at all of the low welding currents, which were $8-8.5 \mathrm{kA}$. Knotting break failure mode was obtained at $8.5 \mathrm{kA}$ ( 25 cycles and 30 cycles). Tearing breaking mode was formed above $9 \mathrm{kA}$ for any of the welding times. During the tests, tearing failure type was obtained from the micro alloyed steel specimens. All of the specimens' failure modes are given in Table $\mathrm{V}$.

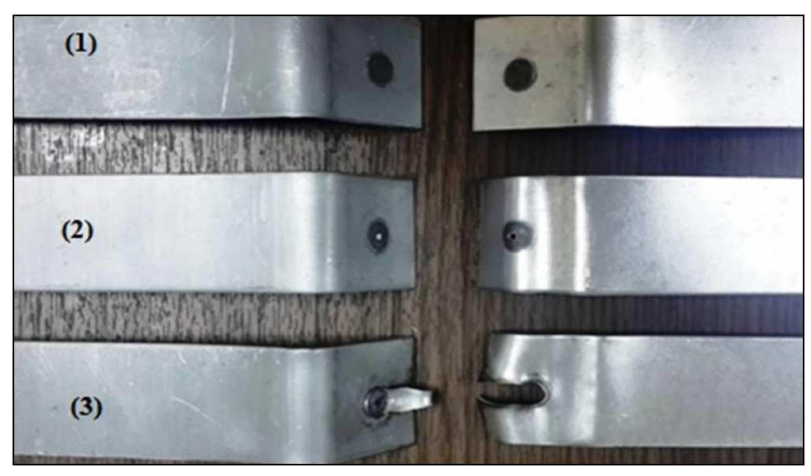

Fig. 2. Breaking failure modes observed in tensile-peel tests.

TABLE V

Breaking failure modes for all specimens.

\begin{tabular}{c|c|c|c}
\hline $\begin{array}{c}\text { Welding } \\
\text { time } \\
\text { [cycles] }\end{array}$ & $\begin{array}{c}\text { Welding } \\
\text { current } \\
{[\mathrm{kA}]}\end{array}$ & $\begin{array}{c}\text { Breaking } \\
\text { failure } \\
\text { mode }\end{array}$ & $\begin{array}{c}\text { Number } \\
\text { of } \\
\text { samples }\end{array}$ \\
\hline \multirow{3}{*}{5} & 10 & Separation & 3 \\
& 10.5 & Separation & 3 \\
$11-16.5$ & Tearing & 30 \\
\hline 10 & $9-16.5$ & Tearing & 36 \\
\hline 15 & $9-16.5$ & Tearing & 36 \\
\hline \multirow{3}{*}{20} & 8.5 & Separation & 3 \\
& 9 & Separation & 3 \\
& 9.5 & Separation & 3 \\
& $10-16.5$ & Tearing & 30 \\
\hline \multirow{2}{*}{25} & 8 & Separation & 3 \\
& 8.5 & Knotting & 3 \\
& $9-15.5$ & Tearing & 30 \\
\hline \multirow{3}{*}{30} & 8 & Separation & 3 \\
& 8.5 & Knotting & 3 \\
& $9-15$ & Tearing & 27
\end{tabular}

The maximum tensile-peel strength was determined. It was found that the tensile-peel strength was increasing by increasing high heat input in welding zone, by increasing welding time and by extending weld nugget. 
The tensile-peel strength of joints was increased by increasing welding current from $9 \mathrm{kA}$ to $16.5 \mathrm{kA}$ for all six welding times. For 5, 10 and 15 periods, a straight increment was obtained in tensile-peel strength, using $16.5 \mathrm{kA}$ current value. It was determined that the maximum value at $10-16.5 \mathrm{kA}$ was $1720 \mathrm{~N}$, and then, after this point, the values were decreasing sharply (Fig. 3). It can be concluded that the excessive heat formation in the welding zone and long welding times were causing these situation. The maximum tensile-peel loads are summarized for each welding time in Table VI.

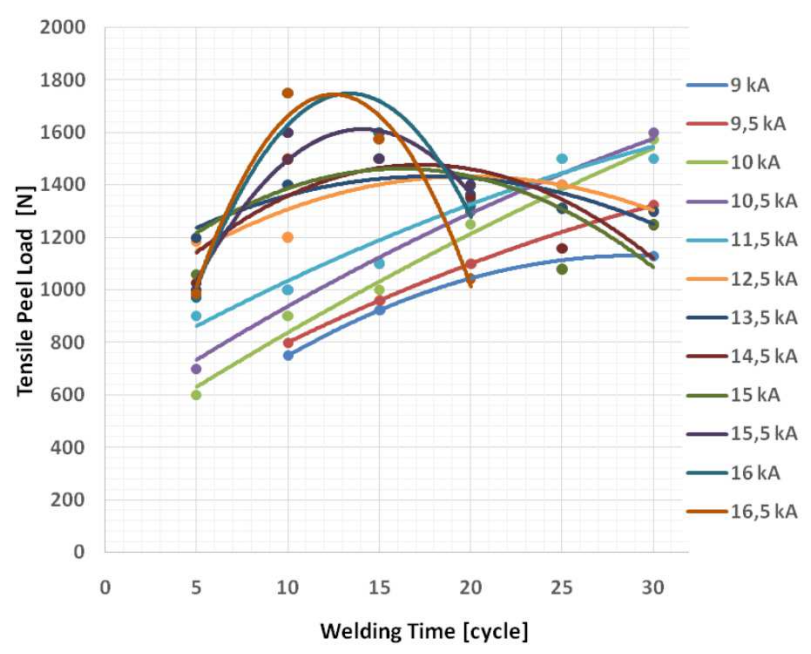

Fig. 3. Effect of welding time on tensile-peel load of weld joints.

TABLE VI

Results of tensile-peel tests.

\begin{tabular}{c|c|c}
\hline \hline $\begin{array}{c}\text { Welding time } \\
\text { [cycles] }\end{array}$ & $\begin{array}{c}\text { Welding current } \\
{[\mathrm{kA}]}\end{array}$ & $\begin{array}{c}\text { Max. tensile-peel } \\
\text { load }[\mathrm{N}]\end{array}$ \\
\hline 5 & 13.5 & 1198 \\
10 & 16.5 & 1660 \\
15 & 16 & 1720 \\
20 & 14.5 & 1460 \\
25 & 11.5 & 1440 \\
30 & 10 & 1600
\end{tabular}

\section{Conclusions}

In this study, the relationship between tensile-peel strength and welding time of two different steel sheets welded using RSW was investigated. The results can be summarized as follows:

1. TRIP 800 and micro alloyed steel sheets were welded successfully using RSW.

2. Three types of breaking failure modes were obtained: (1) separation, (2) knotting, (3) tearing.
3. Low welding currents $(8-8.5 \mathrm{kA})$ were causing separation break failure mode.

4. Knotting break failure mode was obtained infrequently, e.g. at $8.5 \mathrm{kA}$ with 25 cycles and 30 cycles welding time.

5. Tearing breaking mode was formed above $9 \mathrm{kA}$ for all welding times. Tearing breaking failure type was obtained from the micro alloyed steel specimens.

6. The maximum value of tensile-peel strength was determined as $1755 \mathrm{~N}$ using 13 cycles at $16.5 \mathrm{kA}$ welding currents.

7. The tensile-peel strength was increased via increasing welding time.

\section{Acknowledgments}

The authors wish to thank Sakarya University Scientific Research Foundation (project number: FBDTEZ 2015-50-02-018) for their support.

\section{References}

[1] S. Aslanlar, U. Özsaraç, E. Ferik, F. Varol, M. Ekici, in: 14th Int Materials Symp. (IMSP'2012), 2012, p. 833.

[2] S.S. Nayak, V.H. Baltazar Hernandez, Y. Okita, Y. Zhou, Mater. Sci. Engin. A 551, 73 (2012).

[3] O.J. Kwon, K. Leeb, G. Kimc, K.-G. Chind, Mater. Sci. Forum 638-642, 136 (2010).

[4] S. Brauser, L.A. Pepke, G. Weber, M. Rethmeier, Mater. Sci. Engin. A 527, 7099 (2010).

[5] S. Dancette, D. Fabrčgue, V. Massardier, J. Merlin, T. Dupuy, V. Bouzekrib, Mater. Sci. Engin. A 78, 2259 (2011).

[6] A. Al-Mukhtar, Adv. Engin. Forum 17, 31 (2016).

[7] P. Russo Spena, M. De Maddis, F. Lombardi, F. D'Aiuto, Appl. Mech. Mater. 423-426, 876 (2013).

[8] N. Akkaş, E. İlhan, Acta Phys. Pol. A 125, 497 (2014).

[9] M. Balasubramanian, V. Balasubramanian, Acta Meatall. Sin. 23, 185 (2010).

[10] M. Tumuluru, Welding and Joining of Advanced High Strength Steels (AHSS) 2015, 55 (2015).

[11] M.H. Razmpoosh, M. Shamanian, M. Esmailzadeh, Mater. Design 67, 571 (2015).

[12] M. Pouranvari, Mater. Sci. Engin. A 546, 129 (2012). 